\title{
De zin en onzin van opkomst(bevordering)
}

\author{
Julien van Ostaaijen, Daan Jacobs \& Sabine van Zuydam*
}

\begin{abstract}
'Rutte accepteert geen lage opkomst' was de titel van een persbericht van de NOS voorafgaand aan de gemeenteraadsverkiezingen van 2014. De minister-president zou 'iedere kans (...) grijpen om mensen op te roepen te gaan stemmen'. ${ }^{1}$ Rond verkiezingen, met name bij de zogenaamde 'tweede orde'-verkiezingen, zijn dergelijke teksten van bestuurders wel vaker te horen. Er zijn dan ook heel wat activiteiten ondernomen om de opkomst bij verkiezingen te verhogen en die komen zowel van politici als van maatschappelijke instanties en de overheid zelf. Of dat wenselijk en zinvol is, is echter maar de vraag. In deze bijdrage reflecteren we op een aantal hiermee samenhangende vragen als: Wat is eigenlijk een lage opkomst? En waarom is dat erg? Hoe zit dat in Nederland, met name bij zogenaamde 'tweede orde'-verkiezingen? En (hoe) is de opkomst beïnvloedbaar? We verdedigen hierbij de centrale stelling dat overheden zich niet met opkomstbevordering zouden moeten bezighouden. Ze zouden juist de onderliggende redenen van een lage opkomst moeten aanpakken. Dat vergt echter een andere aanpak dan nu doorgaans gekozen wordt.
\end{abstract}

\section{Het probleem van een lage opkomst}

Om te bepalen of overheden zich bezig zouden moeten houden met opkomstbevordering dringt zich allereerst de vraag op of een lage opkomst überhaupt een probleem is. Hoewel veel mensen dat intuïtief met 'ja' zullen beantwoorden, bestaan daarover meerdere opvattingen. Mensen die een lage opkomst betreuren, wijzen er doorgaans op dat hierdoor de belangen van een deel van de samenleving niet worden gehoord of tot uitdrukking komen. Veel niet-stemmers zouden bovendien ontevreden burgers zijn, die uit protest of afkeer van hun stemrecht afzien. Het bestaan van een grote groep niet-stemmers draagt ook niet bij aan een vitale democratie en zet de legitimiteit van het bestuur onder druk. Daartegenover staan beweringen dat over een lage opkomst niet al te dramatisch moet worden gedaan. 'Stemmen is een recht en geen plicht', wordt dan gezegd. Een deel van de niet-stemmers zou bovendien best tevreden zijn en de belangen van de niet-stemmers zouden niet heel veel anders zijn dan die van wel-stemmers. De juistheid van al deze argumenten is niet voor ieder argument even goed onderzocht. Zo weten we dat een deel van de niet-stemmers ontevreden is, maar hoe groot die groep precies is, is onduidelijk. Wel weten we dat de belangen en voorkeuren van de groep niet-stemmers op onderdelen afwijken van die van wel-stem-

* Dr. Julien van Ostaaijen is universitair docent bestuurskunde aan Tilburg University en wetenschappelijk adviseur bij ProDemos: huis voor democratie en rechtsstaat. Daan Jacobs MSc is onderzoeker en docent bestuurskunde aan Tilburg University. Sabine van Zuydam is universitair docent bestuurskunde aan Tilburg University en onderzoeker bij Necker van Naem. 
mers. ${ }^{2}$ Het lijkt er dus op dat de argumenten dat een lage opkomst een probleem is, het meest door de feiten ondersteund worden. Sommige argumenten blijven desalniettemin lastig weerlegbaar, zoals of en hoe de legitimiteit van het openbaar bestuur door een dalende opkomst afneemt.

\section{De verkiezingsopkomst in Nederland in perspectief}

Als we accepteren dat een lage opkomst problematisch is, is de volgende vraag hoe het met die opkomst in Nederland gesteld is. Aangezien er geen internationaal aanvaard opkomstpercentage is waarboven democratieën als 'vitaal' of besturen als 'legitiem' te kwalificeren zijn, is dat een lastig te beantwoorden vraag. Bij verkiezingen waar de opkomst de helft van het aantal kiesgerechtigden nadert, is die 50 procent-grens op zijn minst symbolisch belangrijk. De kwalificatie van de opkomst als hoog of laag is echter vooral subjectief en relatief. In Nederland is de opkomst bij verkiezingen voor Provinciale Staten, gemeenteraad, waterschappen en Europees Parlement bijvoorbeeld laag als we die vergelijken met de opkomst bij Tweede Kamerverkiezingen. Dat is mede de reden dat die verkiezingen ook wel als 'tweede orde'-verkiezingen worden aangeduid. Internationaal gezien is het beeld divers. Vergeleken met België - waar een opkomstplicht geldt - is de opkomst bij alle Nederlandse verkiezingen laag. Anderzijds worden in de Verenigde Staten, toch vaak als schoolvoorbeeld van democratie aangehaald, lang niet altijd hoge(re) opkomsten gehaald. Bij federale verkiezingen en presidentsverkiezingen komt de opkomst vaak niet boven de opkomst van onze gemeenteraadsverkiezingen uit. ${ }^{3}$ Dat heeft ongetwijfeld ook met de relatief grote drempel in de vorm van kiezersregistratie te maken. ${ }^{4}$ En als we de verkiezingsopkomst in Nederland ten slotte vergelijken met andere vormen van politieke participatie in Nederland, dan is stemmen een populaire activiteit. Op lokaal niveau stemde bij de laatste lokale verkiezingen 54 procent van de kiesgerechtigden, maar de op één na meest populaire vorm van politieke participatie op lokaal niveau - het ondertekenen van een petitie - wordt maar door iets meer dan 7 procent van de bevolking gedaan. Andere 'politieke' activiteiten zoals contact opnemen met een politicus of ambtenaar, het lidmaatschap van een politieke partij of actief zijn in een lokale actiegroep scoren nog lager. ${ }^{5}$ In dat perspectief is 54 procent weer erg hoog. ${ }^{6}$ Kortom, de opkomst bij Nederlandse verkiezingen is weliswaar op verschillende manieren als 'behoorlijk' te kwalificeren, maar substantiële verbetering is zeker bij de 'tweede orde'-verkiezingen mogelijk.

\section{De effectiviteit van opkomstbevorderingsmaatregelen}

Een aantoonbaar lage opkomst is op zich nog geen reden waarom overheden zich met opkomstbevordering bezig zouden moeten houden. Dit is namelijk pas verdedigbaar zodra duidelijk is dat zij hier ook daadwerkelijk iets aan kunnen doen. Het feit dat de opkomst uit veel verschillende factoren bestaat of op zijn minst kan bestaan, maakt dat het beïnvloeden van de opkomst lastig is. Volgens de auteurs van een meta-analyse zijn er minstens 176 factoren die op enig moment in 
(wetenschappelijk) opkomstonderzoek zijn onderzocht. ${ }^{7}$ De auteurs vonden echter geen onderzoek waarin al deze factoren zijn meegenomen. Sterker nog, de meest onderzochte factoren/variabelen - leeftijd en opleiding - bleken respectievelijk maar in 72 procent en 74 procent van de onderzochte publicaties te worden meegenomen. Ook overzichtswerken behandelen meestal hooguit enkele tientallen factoren. De auteurs concluderen hieruit onder meer dat er geen wetenschappelijke consensus is (en wellicht ook niet kan zijn) over welke factoren nu behoren tot een 'core-model' van opkomst. ${ }^{8}$ Dat neemt niet weg dat enkele factoren vaak als belangrijke verklarende factoren genoemd worden, ook in recent onderzoek naar lokale verkiezingen in Nederland. Politieke factoren als interesse in politiek, kennis van politiek, vertrouwen in politiek en tevredenheid over de politiek bleken belangrijker dan veel andere voor (de verschillen in) lokale opkomst. Dat geldt ook voor sociaal-demografische factoren als leeftijd, opleiding, gemeentegrootte, inkomen, etniciteit en sociale factoren als levensstijl, geluksgevoel, sociale plicht, sociale druk/omgeving en gewoonte. ${ }^{9}$ De belangrijkste factoren die aan de (lage) opkomst ten grondslag liggen, zijn dus 'structureel', in de zin dat ze doorgaans op korte termijn lastig wezenlijk te beïnvloeden zijn, zoals de opleiding of leeftijdssamenstelling van de bevolking. Dat geldt ook voor politieke factoren als politieke interesse of vertrouwen in de politiek. De activiteiten van overheden rondom verkiezingen lijken echter beperkt in te spelen op deze structurele factoren. Zo ondernamen lokale overheden rondom de gemeenteraadsverkiezingen van 2014 de volgende activiteiten:

Tabel 1 Gemeentelijke communicatie-inzet lokale verkiezingen $2014^{10}$

\begin{tabular}{ll}
\hline Communicatiemiddelen & $\begin{array}{l}\text { Door hoeveel gemeen- } \\
\text { ten ingezet (in \%) }\end{array}$ \\
\hline Geen communicatiemiddelen ingezet & 17 \\
Mensen aanspreken/flyers op straat & 11 \\
Posters, aanplakbiljetten, reclameborden e.d. op straat & 42 \\
Spotjes/uitzendingen op radio of tv & 17 \\
Persoonlijke brieven voor bewoners (bijv. van de burgemeester) & 55 \\
Advertenties/berichten in kranten & 65 \\
Verkiezingskrant/nieuwsbrief aan huis bezorgd & 45 \\
Digitale stemhulp (Kieskompas/Stemwijzer/DeStemVan) & 29 \\
Publiek toegankelijke debatten of verkiezingsmarkten & 59 \\
Digitale media (websites, sociale media, filmpjes op internet) & 74 \\
Overige communicatiemiddelen & 17 \\
\hline
\end{tabular}

Het effect van al deze activiteiten op de opkomst bleek verwaarloosbaar; een statistisch significant effect tussen de inzet van deze middelen en de hoogte van de opkomst werd niet gevonden. Ook ander onderzoek uit het binnen- en buitenland lijkt te bevestigen dat het met dergelijke campagneactiviteiten moeilijk is de opkomst significant te verhogen, zowel door overheden als politieke partijen. Op zijn minst vereist de inzet ervan doorgaans hoge kosten voor een bescheiden toe- 
name van de opkomst. ${ }^{11}$ Bovendien laten veel Nederlandse gemeenten zich bij de inzet van hun activiteiten niet leiden door onderzoek naar de effectiviteit van dergelijke campagnes. Zij kiezen hun activiteiten omdat 'de politiek het [zo] wil' of 'omdat we dat vier jaar geleden ook zo deden'. ${ }^{12}$

\section{Naar een hogere opkomst bij verkiezingen}

Als we de antwoorden op deze vragen bezien, dan lijkt er maar weinig reden te zijn waarom overheden zich met opkomstbevordering bezig zouden moeten houden. Hoewel een lage opkomst op zich als problematisch beschouwd zou kunnen worden en de opkomst bij ('tweede orde'-)verkiezingen in Nederland op punten als laag kan worden aangemerkt, zijn er geen aanwijzingen dat (Nederlandse) overheden erin slagen om hier iets aan te doen. Onze stelling in deze bijdrage luidt dan ook dat overheden zich niet met opkomstbevordering zouden moeten bezighouden. Althans: ze zouden de onderliggende redenen van een lage opkomst moeten aanpakken. Dat vergt een andere aanpak dan die doorgaans gekozen wordt. Wat genuanceerder kunnen we stellen dat als overheden enkel en alleen het opkomstcijfer willen verbeteren, er betere manieren zijn dan de huidige inzet. Denk aan het opnieuw invoeren van de opkomstplicht. Als overheden dat niet willen, bijvoorbeeld omdat het ze om de achterliggende problemen gaat, dan is het goed te beseffen dat structurele problemen een structurele aanpak vereisen. Meer investeren in (democratie- en burgerschaps)onderwijs en de betrokkenheid van inwoners bij politiek en bestuur bijvoorbeeld. Dat vereist grote investeringen en zal de opkomst waarschijnlijk pas op de lange termijn (iets) verhogen. Maar daar ligt wel de sleutel tot succes.

\section{Noten}

1 Rutte: peilingen opkomst te somber, website NOS, 16 maart 2014.

2 Sociaal en Cultureel Planbureau (2002). Niet-stemmers: een onderzoek naar achtergronden en motieven in enquêtes, interviews en focusgroepen. Den Haag: SCP. Voor het lokaal niveau: Stichting KiezersOnderzoek Nederland (2016). Democratie dichterbij. Lokaal kiezersonderzoek 2016. Den Haag: Ministerie van BZK.

3 The American Presidency Project (n.d.). Statistics: Voter Turnout in Presidential Elections 1828-2012. www.presidency.ucsb.edu/statistics/data/voter-turnout-inpresidential-elections, geraadpleegd op 18 januari 2019.

4 Cancela, J., \& Geys, B. (2016). Explaining voter turnout: A meta-analysis of national and subnational elections. Electoral Studies, 42: 264-275.

5 Stichting KiezersOnderzoek Nederland (2016). Democratie dichterbij. Lokaal kiezersonderzoek 2016. Den Haag: Ministerie van BZK. Sociaal en Cultureel Planbureau (2002).

6 Zie ook: Van Ostaaijen, J.J.C. (2018). Tussen eerste overheid en tweederangsdemocratie. Het functioneren van de lokale democratie in Nederland. Den Haag: Boom juridisch.

7 Smets, K., \& Ham, C. van (2013). The embarrassment of riches? A meta-analysis of individual-level research on voter turnout. Electoral Studies, 32 (2): 344-359. 
8 Zie ook: Geys, B. (2006). Explaining voter turnout: A review of aggregate-level research. Electoral studies, 25 (4): 637-663.

9 Van Ostaaijen, J.J.C., Epskamp, M., \& Dols, M. (2016). Verbetering op komst. Een verkenning naar een effectieve gemeentelijke inzet van communicatiemiddelen voor de opkomst bij lokale verkiezingen. Tilburg: Universiteit van Tilburg/Rotterdam: OBI Rotterdam.

10 Van Ostaaijen e.a. (2016).

11 Green, D.P., \& Gerber, A.S. (2015). Get Out the Vote: How to Increase Voter Turnout. Washington D.C., Columbia: Brookings Institution Press; Van Zuydam, S., Jacobs, D., \& Van Ostaaijen, J. (2018). Gaat u ook stemmen? Het effect van communicatie op de opkomst bij gemeenteraadsverkiezingen. Tilburg: Universiteit van Tilburg.

12 Van Ostaaijen e.a. (2016). 